\title{
Incidence and Impact of COVID-19 in MS
}

\section{A Survey From a Barcelona MS Unit}

\author{
Maria Sepúlveda, MD, * Sara Llufriu, MD, PhD, * Eugenia Martínez-Hernández, MD, PhD, Martí Català, MSc, \\ Montse Artola, RN, Ana Hernando, RN, Carmen Montejo, MD, Irene Pulido-Valdeolivas, MD, PhD, \\ Eloy Martínez-Heras, PhD, Mar Guasp, MD, Elisabeth Solana, PhD, Laura Llansó, MD, \\ Domingo Escudero, MD, PhD, Marta Aldea, MD, MPH, Clara Prats, PhD, Francesc Graus, MD, PhD, \\ Yolanda Blanco, MD, PhD, $†$ and Albert Saiz, MD, PhD $\dagger$
}

Neurol Neuroimmunol Neuroinflamm 2021;8:e954. doi:10.1212/NXI.0000000000000954

\section{Abstract}

\section{Objective}

To investigate the incidence of coronavirus disease 2019 (COVID-19) in a single-center cohort of patients with MS and to explore the contribution of their comorbidities and therapies to the outcome.

\section{Methods}

A cross-sectional mixed-method study was conducted involving an email-based, selfadministered questionnaire sent on May 21, 2020, to 586 patients with MS followed at the MS Unit of Hospital Clinic, University of Barcelona, along with telephone interview, and review of electronic medical records until June 18, 2020. The cumulative incidence of confirmed COVID-19 (positive PCR or antibody test) and all COVID-19 cases (confirmed and suspected) from the start of the pandemic was compared with the population estimates for Barcelona.

\section{Results}

A total of 407 patients (69.5\%) completed the survey. Most of the responders (67\%) were female. The responders had a median age of 48 years (range 19-86), relapsing-remitting disease (84\%), at least 1 comorbidity (45\%), and were on disease-modifying therapy (DMT; 74.7\%). COVID-19 was confirmed in 5 patients $(1.2 \%)$ and suspected in $46(11.3 \%)$. The cumulative incidence of confirmed COVID-19 cases was similar to that of the general population but was almost 2 -fold higher when all cases were considered $(p<0.001)$. Six patients $(11.7 \%)$ were hospitalized, of which 5 had good recovery and 1 died. Hospitalized patients were more frequently male, had diabetes and had progressive forms of MS $(p<0.05)$. DMT was not associated with the risk of infection or the outcome.

\section{Conclusions}

In the studied MS cohort, the incidence of COVID-19 was higher than that of the general population; however, most patients did not require hospitalization and had a good outcome despite the frequent presence of comorbidities and treatment with DMT.

\author{
Correspondence \\ Dr. Saiz \\ asaiz@clinic.cat
}

\section{COVID-19 Resources}

MORE ONLINE

For the latest articles, invited commentaries, and blogs from physicians around the world NPub.org/COVID19

\footnotetext{
*These authors contributed equally to the manuscript.

tThese authors share senior authorship.

From the Neuroimmunology and Multiple Sclerosis Unit (M.S., S.L., E. Martínez-Hernández, M. Artola, A.H., C.M., I.P.-V., E. Martínez-Heras, M.G., E.S., L.L., D.E., Y.B., A.S.), Service of Neurology, Hospital Clinic, Institut d'Investigacions Biomèdiques August Pi i Sunyer (IDIBAPS), and Universitat de Barcelona; Comparative Medicine and Bioimage Centre of Catalonia (CMCiB) (M.C., C.P.), Fundació Institut d'Investigació en Ciències de la Salut Germans Trias i Pujol; Department of Physics (M.C., C.P.), Universitat Politècnica de Catalunya; Preventive Medicine and Epidemiology Department (M. Aldea), Hospital Clinic of Barcelona, University of Barcelona; Neuroimmunology Program (F.G.), Institut d'Investigacions Biomèdiques August Pi i Sunyer (IDIBAPS); and Institut de Neurociències (A.S.), Universitat de Barcelona, Spain.

Go to Neurology.org/NN for full disclosures. Funding information is provided the end of the article. 


\section{Glossary}

DMT = disease-modifying therapy; EDSS = Expanded Disability Severity Scale; ICU = intensive care unit; SARS-CoV-2 = severe acute respiratory syndrome coronavirus 2; WHO = World Health Organization.

Severe acute respiratory syndrome coronavirus 2 (SARSCoV-2), the causative virus of the coronavirus disease 2019 (COVID-19) pandemic, has high mortality in a vulnerable population with chronic diseases, including those who are treated with immunosuppressive therapies. ${ }^{1,2}$ Patients with MS have a chronic inflammatory disorder, are usually treated with immunosuppressive or immunomodulatory therapies, and frequently have several comorbidities that have been related to worse COVID-19 prognosis. $^{3-5}$ It is currently unclear whether patients with MS have an increased susceptibility to develop COVID-19 and worse outcomes compared with the general population; some studies even suggest that immunotherapy could be a protective factor against worse COVID-19 outcome, ${ }^{3,4,6}$ but they have not compared the incidence and mortality estimates of COVID-19 in patients with MS with those of the general population.

In response to the COVID-19 pandemic, finding answers to these questions is important if we want to make appropriate decisions and implement protective strategies. Toward the end of February 2020, Barcelona was one of the earliest cities in Spain to be affected by COVID-19. This led to a 3-month confinement of the population and provided an opportunity to address the aforementioned issues. Therefore, we conducted a cross-sectional study to investigate potential differences between the incidence of COVID-19 in a large cohort of patients with MS and the general population of the city of Barcelona. In addition, we explore the effect of patient comorbidities and therapies on the COVID-19 outcome.

\section{Methods}

This was a cross-sectional mixed-method study involving an email-based, self-administered questionnaire sent to the cohort of patients with MS followed at the Neuroimmunology and MS Unit of Hospital Clinic of Barcelona (patients aged $\geq 18$ years), coupled with a telephone interview, and review of electronic health records. On May 21, 2020, an email that included the aim of the study, the information on the approval by the Ethic Committee, and 3 questions that could be answered by replying to the same email was sent to 586 patients. The questions were the following: (1) Have you had COVID19 infection?: Yes or No, and if Yes: confirmed by PCR or SARS-CoV-2 serology or diagnosed by a doctor without confirmation; (2) Have you had any of these symptoms that the World Health Organization (WHO) considered suspicious: fever and at least 1 sign/symptom of a respiratory disease, e.g., cough, shortness of breath, ${ }^{7}$ or had one of these symptoms together with loss of smell and taste?; and (3) Do you consent to have a telephone interview by a doctor from the MS Unit to clarify any additional information such as admission to the hospital and symptoms of relapse? The telephone interview was conducted within 4 weeks after the email was sent. For the identification of potential participants, we also cross-checked our databases of patients and therapies (iMED v 6.6.4) with the records of admitted cases of COVID19 available at the hospital. The following variables were retrieved from the hospital electronic record: age, sex, presence/ absence of comorbidities related to SARS-CoV-2 infection (smoking, hypertension, dyslipidemia, diabetes mellitus, cardiovascular disease, chronic lung disease, and neoplasm), and admission to the hospital and/or intensive care unit (ICU). The MS history including the Expanded Disability Severity Scale (EDSS) score and relapses was collected from our MSspecific database (iMED v 6.6.4).

Patients were confirmed to have COVID-19 if they had a positive PCR or antibody test result. Patients were suspected to have COVID-19 if they were diagnosed by a clinician without PCR or serologic confirmation, and (1) had typical SARS-CoV-2 pneumonia findings in their chest X-ray or CT, (2) had symptoms considered suspicious by the WHO (fever and 1 or more sign/symptom of a respiratory disease), or (3) had fever or a respiratory symptom in addition to anosmia and/or ageusia. The COVID-19 course was classified as mild for patients who did not require hospitalization or oxygen administration, severe for hospitalized patients, and critical illness for those who required admission to the ICU and/or mechanical ventilation.

\section{Standard Protocol Approvals, Registrations, and Patient Consents}

The email also collected consent to participate in the study. Utilization of medical data was carried out according to the Spanish law and the General Data Protection Regulation. The study received approval from the Ethic Committee of Hospital Clinic (HCB/2020/0600).

\section{Data Availability}

Anonymized data will be made available on request from any qualified investigator. No deidentified patient data or studyrelated documents will be shared.

\section{Statistical Analysis}

Demographic and clinical characteristics between responders and nonparticipants to the email, between all patients with COVID-19 (confirmed and suspected) and without COVID19 , and between patients with COVID-19 and severe or mild course were compared using $\chi^{2}$ (or Fisher exact) tests for categorical data and the Student $t$ test (or Mann-Whitney $U$ test) for continuous data. Disease-modifying therapies 
(DMTs) were grouped according to potential infection risk (no risk: interferon beta and glatiramer; low risk: teriflunomide, dimethyl fumarate, and natalizumab; intermediate or high risk: fingolimod, anti-CD20 therapies, cladribine, and alemtuzumab) as proposed in previous studies. ${ }^{3}$ Two-sided $p$ $<00.05$ was considered statistically significant. Cumulative incidence in the MS cohort was adjusted by sex and age, using the Barcelona population as reference. Cumulative incidence in Barcelona was calculated using the data of an epidemiologic database from the city generated by the local health system, which is updated daily and contains district-level information of confirmed and suspected COVID-19 cases. ${ }^{9}$ Cumulative cases were updated from this database until June 18, 2020. Data series of Barcelona of confirmed cases (positive PCR or antibody test) and all COVID-19 cases (confirmed and suspected cases) were analyzed independently and compared with data obtained from patients with MS. We compared our data with those of the city because almost $40 \%$ of our patients belong to city health areas not covered by our hospital. Statistical analysis of these data was performed with MATLAB and Excel.

Univariate and multivariate logistic regression models were performed on identified variables to assess their association with COVID-19 infection and outcome. We conducted a multivariate stepwise logistic regression analysis with hospitalization as the dependent variable and age, sex, EDSS, MS disease phenotype (relapsing-remitting vs progressive), comorbidities, and DMT level as independent variables. Results were expressed as OR and 95\% CI. Data analyses were performed with SPSS statistics package version 25 .

\section{Results}

As of June 18, 2020, 407 patients (69.5\%) completed the survey. Two hundred seventy-three responders (67\%) were female, with a median age of 48 years (range 19-86 years) and a mean (SD) disease duration of 15 (9.6) years (table 1). No significant demographic differences were found between the participants and those who did not respond to the survey, but the former more frequently had relapsing-remitting MS forms ( $84 \%$ vs $72 \%, p=0.007$ ), had a lower EDSS score (mean 2.6 [1.9] vs 2.9 [2.2], $p=0.029$ ), and were more frequently on DMT (75\% vs 58\%, $p<0.001$ ) (table e-1, links.lww.com/ NXI/A396).

\section{Cumulative Incidence of COVID-19}

Of the 407 responders, 5 (1.2\%) were confirmed and 46 (11.3\%) were suspected COVID-19 cases (table 1). The cumulative incidence of confirmed cases adjusted by sex and age was not significantly different from that of Barcelona city (1.27\%, 95\% CI $0.18-2.36$ vs $1.32 \%$, 95\% CI 1.30-1.34), but it was 1.74-fold higher for all COVID-19 cases (confirmed and suspected) (11.65\%, 95\% CI 9.31-15.75 vs $6.69 \%$, 95\% CI 6.65-6.73, $p<0.001$ ) (table 2). Similar results were found when the estimates were compared with the population of the geographic area covered by Hospital Clinic in Barcelona (eResults, links.lww.com/NXI/A395).

\section{Demographic and Clinical Characteristics of Patients With COVID-19}

Clinical and demographic data of the 51 COVID-19 cases ( 5 confirmed and 46 suspected) and 356 patients without COVID-19 are summarized in table 1. Patients with COVID19 were younger (mean 44.9 [10.8] years vs 49.4 [12.3] years, $p=0.016)$ and had a lower frequency of comorbidities $(31 \%$ vs $47 \%, p=0.047$ ) than those without COVID-19 (table 1 ). There were no significant differences between the 5 patients with confirmed and the 46 with suspected COVID-19 (table e-2, links.lww.com/NXI/A397) or the 356 non-COVID-19 cases (table e-3, links.lww.com/NXI/A398).

Forty-five of the 51 (88.2\%) patients with COVID-19 had mild disease that did not require hospitalization. The remaining $6(11.8 \%)$ were admitted to the hospital, but only 1 died. This patient was a 71-year-old man with primary progressive MS, who was admitted to the emergency department with severe respiratory distress (bilateral pneumonia) and died a few hours later; none of the other 5 patients required ICU admission. One of the patients was readmitted 2 weeks after discharge for bronchiolitis obliterans with organized pneumonia that responded to prednisone therapy.

\section{Variables Associated With COVID-19 Severity and Mortality}

Compared with the patients who had a mild course, those hospitalized were more frequently male (5/6 [83\%] vs $12 / 45$ [26.6\%], $p=0.012)$, more frequently had diabetes $(2 / 6$ [33.3\%] vs $0 / 45, p=0.012)$, and had a progressive MS form $(3 / 6[50 \%]$ vs $5 / 45[11 \%], p=0.042)$ (table 3). Significant risk factors associated with hospitalization in the univariate logistic regression models were male sex (OR 13.08, 95\% CI 1.39-122.85, $p=0.024$ ) and progressive MS (OR 8.4, 95\% CI $1.32-53.3, p=0.024)$. In the multivariate logistic regression model, male sex was retained as an independent variable (OR $12.56,95 \%$ CI $1.21-130.78, p=0.034)$, whereas a trend was observed for progressive MS type (OR 7.93, 95\% CI $0.97-64.78, p=0.053$ ).

No data of hospitalizations in Barcelona during the study period were available. The mortality rate, including confirmed and suspected cases, in the MS cohort was not significantly different from that of the population of the city $(1 / 51$ [1.9\%] vs $4,243 / 96,456$ [4.39\%], $p=0.41)$ or the geographical area covered by Hospital Clinic $(1 / 51$ [1.9\%] vs $1,211 / 27,960$ [4.3\%], $p=0.4$ (e-Results, links.lww.com/NXI/A395).

\section{Discussion}

This epidemiologic survey of COVID-19 incidence in a large cohort of patients with MS from a tertiary hospital of Barcelona covering the first 4 months of the pandemic provides 
Table 1 Demographic and Clinical Characteristics of Patients With or Without COVID-19

\begin{tabular}{|c|c|c|c|}
\hline & All COVID-19 $(n=51)$ & No COVID-19 $(n=356)$ & $p$ Value \\
\hline Female, $\mathrm{n}(\%)$ & $34(66.7)$ & $239(67.1)$ & 0.947 \\
\hline Age at survey, $y$, median (range) & $44(19-69)$ & $48(20-86)$ & 0.016 \\
\hline At least 1 comorbid condition, $n(\%)$ & $16(31.0)$ & $167(47.1)$ & 0.047 \\
\hline Smoking & $7(13.7)$ & $65(18.2)$ & 0.835 \\
\hline Dyslipidemia & $5(9.8)$ & $78(21.9)$ & 0.061 \\
\hline Diabetes & $2(3.9)$ & $24(6.7)$ & 0.755 \\
\hline Hypertension & $4(7.8)$ & $54(15.1)$ & 0.195 \\
\hline Heart disease & 0 & $8(2.2)$ & 0.599 \\
\hline Pulmonary disease & $2(3.9)$ & $17(4.8)$ & 1.00 \\
\hline Malignancy & 0 & $8(2.2)$ & 0.599 \\
\hline \multicolumn{4}{|l|}{ MS type, n (\%) } \\
\hline RRMS & $43(84.3)$ & $298(83.7)$ & \\
\hline SPMS & $5(9.8)$ & $31(8.7)$ & 0.853 \\
\hline PPMS & $3(5.9)$ & $22(6.2)$ & \\
\hline CIS & 0 & $5(1.4)$ & \\
\hline Disease duration, $y$, mean (SD) & $12.6(8.4)$ & $15.4(9.7)$ & 0.143 \\
\hline Annualized relapse rate, mean (SD) & $0.6(1.6)$ & $0.4(0.3)$ & 0.214 \\
\hline Last EDSS score, median (range) & $1.5(0-6.5)$ & $2.0(0-8.0)$ & 0.207 \\
\hline Disease-modifying treatment, $\mathrm{n}(\%)$ & $40(78.4)$ & $264(74.1)$ & 0.538 \\
\hline Interferon beta & $6(15)$ & $60(22.6)$ & \\
\hline Glatiramer acetate & $6(15)$ & $35(13.2)$ & \\
\hline Dimethyl fumarate & $10(25)$ & $50(18.9)$ & \\
\hline Teriflunomide & $5(12.5)$ & $30(11.3)$ & \\
\hline Ocrelizumab & $3(7.5)$ & $10(3.7)$ & \\
\hline Rituximab & $4(10)$ & $17(6.4)$ & 0.106 \\
\hline Natalizumab & $1(2.5)$ & $14(5.3)$ & \\
\hline Fingolimod & $2(5)$ & $34(12.8)$ & \\
\hline Alemtuzumab & $1(2.5)$ & $4(1.5)$ & \\
\hline Cladribine & $2(5)$ & $5(1.9)$ & \\
\hline Ofatumumab & 0 & $2(0.7)$ & \\
\hline Azathioprine & 0 & $1(0.3)$ & \\
\hline Ponesimod & 0 & $2(0.7)$ & \\
\hline Patients who developed MS relapse during the study period, $\mathbf{n}(\%)$ & $1(2)$ & $6(1.7)$ & 0.906 \\
\hline
\end{tabular}

Abbreviations: CIS = clinically isolated MS; EDSS = Expanded Disability Severity Scale; PPMS = primary progressive MS; RRMS = relapsing-remitting MS; SPMS = secondary progressive MS.

several important observations: (1) the cumulative incidence of confirmed COVID-19 cases is similar to that of the general population, but it is almost 2 -fold higher when suspected cases are included in the analysis; (2) the MS clinical profile and the type of DMT are not associated with the risk of having COVID19; (3) the clinical outcome of patients with MS with confirmed 
Table 2 Cumulative Incidence Rates of COVID-19 in Our MS Cohort and Barcelona City (BCN) Population

\begin{tabular}{|c|c|c|c|c|c|c|c|}
\hline \multirow[b]{2}{*}{ Age group, y } & \multirow[b]{2}{*}{ Sex } & \multicolumn{2}{|l|}{ Confirmed cases } & \multicolumn{2}{|l|}{ Suspected cases } & \multicolumn{2}{|l|}{ All COVID-19 cases } \\
\hline & & $\begin{array}{l}\text { Cumulative } \\
\text { incidence in BCN }\end{array}$ & $\begin{array}{l}\text { Crude } \\
\text { cumulative } \\
\text { incidence MS } \\
\text { cohort }\end{array}$ & $\begin{array}{l}\text { Cumulative } \\
\text { incidence in BCN }\end{array}$ & $\begin{array}{l}\text { Crude } \\
\text { cumulative } \\
\text { incidence MS } \\
\text { cohort }\end{array}$ & $\begin{array}{l}\text { Cumulative } \\
\text { incidence in BCN }\end{array}$ & $\begin{array}{l}\text { Crude } \\
\text { cumulative } \\
\text { incidence MS } \\
\text { cohort }\end{array}$ \\
\hline \multirow[t]{2}{*}{$18-34$} & $\mathrm{~F}$ & $\begin{array}{l}1,466 / 172,926 \\
(0.85 \%)\end{array}$ & $0 / 24$ & $\begin{array}{l}8,971 / 172,926 \\
(5.19 \%)\end{array}$ & $4 / 24(16.67 \%)$ & $\begin{array}{l}10,437 / 172,926 \\
(6.04 \%)\end{array}$ & $4 / 24(16.67 \%)$ \\
\hline & $\mathrm{M}$ & $\begin{array}{l}887 / 168,294 \\
(0.53 \%)\end{array}$ & $1 / 19(5.26 \%)$ & $\begin{array}{l}4,952 / 168,294 \\
(2.94 \%)\end{array}$ & $2 / 19(10.53 \%)$ & $\begin{array}{l}5,839 / 168,294 \\
(3.47 \%)\end{array}$ & $3 / 19(15.79 \%)$ \\
\hline \multirow[t]{2}{*}{$35-44$} & $\mathrm{~F}$ & $\begin{array}{l}1,392 / 135,178 \\
(1.03 \%)\end{array}$ & $0 / 87$ & $\begin{array}{l}8,102 / 135,178 \\
(5.99 \%)\end{array}$ & 15/87 (17.24\%) & $\begin{array}{l}9,495 / 135,178 \\
(7.02 \%)\end{array}$ & 15/87 (17.24\%) \\
\hline & $\mathrm{M}$ & $\begin{array}{l}956 / 136,294 \\
(0.70 \%)\end{array}$ & $0 / 30$ & $\begin{array}{l}4,340 / 136,294 \\
(3.18 \%)\end{array}$ & $4 / 30(13.33 \%)$ & $\begin{array}{l}5,296 / 136,294 \\
(3.89 \%)\end{array}$ & $4 / 30(13.33 \%)$ \\
\hline \multirow[t]{2}{*}{$45-54$} & $\mathrm{~F}$ & $\begin{array}{l}1,581 / 127,508 \\
(1.24 \%)\end{array}$ & $2 / 90(2.22 \%)$ & $\begin{array}{l}8,060 / 127,508 \\
(6.32 \%)\end{array}$ & $9 / 90$ (10.00\%) & $\begin{array}{l}9,641 / 127,508 \\
(7.56 \%)\end{array}$ & $11 / 90(12.22 \%)$ \\
\hline & $\mathrm{M}$ & $\begin{array}{l}1,200 / 123,770 \\
(0.97 \%)\end{array}$ & $0 / 34$ & $\begin{array}{l}4,637 / 123,770 \\
(3.75 \%)\end{array}$ & $5 / 34(14.71 \%)$ & $\begin{array}{l}5,837 / 123,770 \\
(4.72 \%)\end{array}$ & $5 / 34(14.71 \%)$ \\
\hline \multirow[t]{2}{*}{$55-64$} & $\mathrm{~F}$ & $\begin{array}{l}1,595 / 114,342 \\
(1.39 \%)\end{array}$ & $0 / 47$ & $\begin{array}{l}7,452 / 114,342 \\
(6.52 \%)\end{array}$ & $4 / 47(8.51 \%)$ & $\begin{array}{l}9,047 / 114,342 \\
(7.91 \%)\end{array}$ & $4 / 47$ (8.51\%) \\
\hline & $\mathrm{M}$ & $\begin{array}{l}1,325 / 98,956 \\
(1.34 \%)\end{array}$ & $2 / 30(6.67 \%)$ & $\begin{array}{l}4,735 / 98,956 \\
(4.78 \%)\end{array}$ & $0 / 30$ & $\begin{array}{l}6,060 / 98,956 \\
(6.12 \%)\end{array}$ & $2 / 30(6.67 \%)$ \\
\hline \multirow[t]{2}{*}{$>65$} & $\mathrm{~F}$ & $\begin{array}{l}5,231 / 217,758 \\
(2.40 \%)\end{array}$ & $0 / 25$ & $\begin{array}{l}15,879 / 217,758 \\
(7.29 \%)\end{array}$ & $0 / 25$ & $\begin{array}{l}21,110 / 217,758 \\
(9.69 \%)\end{array}$ & $0 / 25$ \\
\hline & $\mathrm{M}$ & $\begin{array}{l}3,441 / 146,670 \\
(2.35 \%)\end{array}$ & $0 / 21$ & $\begin{array}{l}10,253 / 146,670 \\
(6.99 \%)\end{array}$ & $3 / 21(14.29 \%)$ & $\begin{array}{l}13,694 / 146,670 \\
(9.34 \%)\end{array}$ & $3 / 21(14.29 \%)$ \\
\hline All & All & $\begin{array}{l}19,075 / 1,441,696 \\
(1.32 \%, 95 \% \mathrm{Cl} \\
1.30-1.34)\end{array}$ & $\begin{array}{l}5 / 407(1.23 \%, \mathrm{Cl} \\
0.02-2.30)\end{array}$ & $\begin{array}{l}\text { 77,381/1,441,696 } \\
(\mathbf{5 . 3 7 \% , 9 5 \% ~ C l} \\
5.33-5.40)\end{array}$ & $\begin{array}{l}46 / 407(11.30 \% \\
C I 8.23-14.38)\end{array}$ & $\begin{array}{l}96,456 / 1,441,696 \\
(6.69 \%, 95 \% \mathrm{Cl} \\
6.65-6.73)\end{array}$ & $\begin{array}{l}51 / 407(\mathbf{1 2 . 5 3 \%}, \\
\mathrm{Cl} 9.31-15.75)\end{array}$ \\
\hline $\begin{array}{l}\text { Sex- and age- } \\
\text { adjusted } \\
\text { cumulative } \\
\text { incidence }\end{array}$ & & & $\begin{array}{l}1.27 \%, C l \\
0.18-2.36 \\
{ }^{*} p>0.05\end{array}$ & & $\begin{array}{l}10.38 \%, \mathrm{Cl} \\
7.42-13.34 \\
{ }^{*} p<0.0001\end{array}$ & & $\begin{array}{l}11.65 \%, \mathrm{Cl} \\
8.53-14.77 \\
{ }^{*} p<0.0001\end{array}$ \\
\hline
\end{tabular}

* vs cumulative incidence in BCN.

or suspected COVID-19 is good, with a mortality rate similar to that of the general population; and (4) male sex and a progressive MS form are the main risk factors to be hospitalized.

The incidence of COVID-19 in people with MS compared with that of the general population is unknown. Our study shows an almost 2-fold increase in the incidence of COVID-19 in patients with MS compared with the general population. The low frequency of confirmed cases was expected because in Barcelona during the period of the study, PCR testing was restricted to patients who were admitted to hospitals, and even patients with typical symptoms and bilateral pneumonia were not always tested. In fact, the ratio of suspected/confirmed COVID-19 in the general population of Barcelona was 4, but it was 2.5 times higher in our MS population (table 2). The latter is not unexpected taking into account that people with MS are considered a vulnerable population, and it is likely that this led them to more frequent health care consultations than the general population. Nevertheless, we did not find any difference regarding demographic or MS-related features between patients with confirmed and suspected COVID-19; however, the information should be taken with caution given the small sample size.

In our cohort, patients with COVID-19 were younger and had comorbidities less frequently than those without COVID-19. The mean age of our patients was similar to that reported in a French study with 347 patients $^{3}$ and a study from New York city with 76 patients, ${ }^{10}$ suggesting that patients with MS who are older and have more comorbidities undergo a stricter confinement. This hypothesis is supported by the association found between younger age of patients with COVID-19 with higher exposure to possible sources of infection, as reported in 2 large studies of MS conducted in Europe and the United States ${ }^{11,12}$ and in a study of patients with rheumatic diseases treated with biological and synthetic diseasemodifying antirheumatic drugs carried out in Barcelona. ${ }^{13}$ This fact, and more frequent medical consultation due to 
Table 3 Demographics and Clinical Features of Patients With Severe and Mild COVID-19 Course

\begin{tabular}{|c|c|c|c|}
\hline Patients with COVID-19 $(n=51)$ & Severe COVID-19 $(n=6)$ & Mild COVID-19 $(n=45)$ & $p$ Value \\
\hline Female, n (\%) & $1(16.7)$ & $33(73.3)$ & 0.012 \\
\hline Age at survey, $y$, median (range) & $43(28-69)$ & $44(19-69)$ & 0.921 \\
\hline At least 1 comorbid condition, $n(\%)$ & $2(33.3)$ & $14(31.1)$ & 0.912 \\
\hline Smoking & 0 & $7(15.6)$ & 1.00 \\
\hline Dyslipidemia & $1(16.7)$ & $4(8.9)$ & 0.538 \\
\hline Diabetes & $2(33.3)$ & $0(0)$ & 0.012 \\
\hline Hypertension & 0 & $4(8.9)$ & 1.00 \\
\hline Heart disease & 0 & 0 & 1.00 \\
\hline Pulmonary disease & 0 & $2(4.4)$ & 1.00 \\
\hline Malignancy & 0 & 0 & 1.00 \\
\hline \multicolumn{4}{|l|}{ MS type, n (\%) } \\
\hline RRMS & $3(50)$ & $40(88.9)$ & \\
\hline SPMS & $2(33.3)$ & $3(6.7)$ & 0.042 \\
\hline PPMS & $1(16.7)$ & $2(4.4)$ & \\
\hline Disease duration, $y$, mean (SD) & $14.6(11.6)$ & $12.2(7.8)$ & 0.827 \\
\hline Annualized relapse rate, mean (SD) & $0.3(0.3)$ & $0.6(1.5)$ & 0.249 \\
\hline Last EDSS score, median (range) & $2.5(1.0-7.5)$ & $1.5(0-6.5)$ & 0.077 \\
\hline Disease-modifying treatment, $\mathrm{n}(\%)$ & $4(66.7)$ & $36(80.0)$ & 0.598 \\
\hline Interferon beta & 0 & $6(16.7)$ & \\
\hline Glatiramer acetate & 0 & $6(16.7)$ & \\
\hline Dimethyl fumarate & $2(50)$ & $8(22.2)$ & \\
\hline Teriflunomide & $1(25)$ & $4(11.1)$ & \\
\hline Ocrelizumab & 0 & $3(8.3)$ & 0.734 \\
\hline Rituximab & $1(25)$ & $3(8.3)$ & \\
\hline Natalizumab & 0 & $1(2.8)$ & \\
\hline Fingolimod & 0 & $2(5.5)$ & \\
\hline Alemtuzumab & 0 & $1(2.8)$ & \\
\hline Cladribine & 0 & $2(5.5)$ & \\
\hline
\end{tabular}

Abbreviations: CIS = clinically isolated MS; EDSS = Expanded Disability Severity Scale; PPMS = primary progressive MS; RRMS = relapsing-remitting MS; SPMS = secondary progressive MS.

patients' concern of an increased risk associated with therapy, would explain the increased incidence of COVID-19 observed in our study. However, we cannot rule that the observed increase in MS could be reflecting an underestimation of COVID-19 cases in the general population. We did not identify other differential features between patients with and those without COVID-19, including exposure to DMT or association with comorbidities that could explain a higher risk of infection in those patients. Other studies have also suggested a higher prevalence of COVID-19 in people with $\mathrm{MS}^{14}$ or an excess of COVID-19-infected patients on anti-CD20 therapies. ${ }^{10,15,16}$
Despite the increased incidence of COVID-19 in our cohort of patients with MS, the hospitalization rate $(11.8 \%)$ and mortality (1.9\%) were low. These rates are in line with the data of other studies characterized by a low percentage of confirmed cases. For example, a UK community-based study with $15.6 \%$ of confirmed cases reported $1.3 \%$ of hospitalizations and no deaths; a European and US study with $17 \%$ of confirmed cases described $5.6 \%$ of hospitalizations and no deaths; and an Italian programme with $24.5 \%$ of confirmed cases reported $4 \%$ of patients with mild disease and $2.1 \%$ of mortality. In contrast, higher rates of hospitalization $(21 \%-25.6 \%)$ 
and mortality $(3.5 \%-7.9 \%)$ were reported in studies that included a high proportion of confirmed cases $(42 \%-50 \%))^{3,10,18}$ Taken together, these data suggest a bias toward the confirmation of more severe cases. Nevertheless, consistent reports of a relatively young age of patients with MS with COVID-19 appear to be related to the observed favorable course of the disease in this setting.

Although infections are a known cause of pseudo-relapses in patients with MS, few patients reported a worsening of preexisting symptoms or were seen for a relapse during this period. Because this information is infrequently reported in other series, the exact impact that the pandemic has had in terms of clinical disease activity is currently unknown.

In our study, male sex and progressive MS forms were identified as risk factors for COVID-19 severity, and these together with age, disability, and some comorbidities such as obesity, diabetes, and hypertension have been described in other series. ${ }^{3,10}$ It is noteworthy that most reports $3,6,10,11,17,18$ have not identified an association between DMT exposure and COVID-19 severity; however, a recent Italian study ${ }^{15}$ found not only an increased frequency of anti-CD20 therapy in patients with COVID-19 but also a higher frequency of severe course compared with other DMTs. This finding needs to be confirmed with large population-based studies or larger registry studies.

Our study has several limitations. The study design depends on self-reported data and survey response rates, and although the latter was high $(\sim 70 \%)$, differences were found between responders and nonresponders, which may suggest a selection bias. On the contrary, we conducted a telephone interview and cross-checked our database of patients and therapy with the records of patients with COVID-19 admitted to the hospital to improve case ascertainment. In addition, throughout the study period, patients were contacted to reschedule their ambulatory visits, and instead, had a telephone visit that would have identified nonresponders with more severe illness or hospitalized elsewhere; however, we did not identify any other confirmed or suspected COVID-19 case. The low proportions of patients who were SARS-CoV-2 PCR-tested (9.8\%) may have had an impact on estimates of incidence as mentioned above but not in the observed favorable outcome. In addition, confirmed cases were not different from the suspected COVID-19 cases with respect to demographic or MS disease-related characteristics.

\section{Acknowledgment}

The study has been possible thanks to the transfer of anonymized data by Agència de Qualitat i Avaluació Sanitàries de Catalunya (AQuAS) within the framework of the "PADRIS Program."

\section{Study Funding}

This study was supported in part by Red Española de Esclerosis Múltiple (RD16/0015/0002; RD16/0015/0003) integrated in the Plan Estatal de Investigación Científica y
Técnica de Innovación I+D+I and cofunded by the Instituto de Salud Carlos III-Subdirección General de Evaluación and the Fondo Europeo de Desarrollo Regional (FEDER, "Otra manera de hacer Europa." E. Martínez-Hernández is a recipient of a Juan Rodés grant (JR17/00012) from ISCIII, Madrid, Spain. C. Montejo is a recipient of a grant from Instituto de Salud Carlos III (PFIS, FI19/00111). M. Guasp is a recipient of a Resident Award Josep Font, granted by Hospital Clínic de Barcelona, Research, Innovation and Education Departments. C. Prats and M. Català received funding from La Caixa Foundation (ID 100010434), under agreement LCF/PR/GN17/50300003, and from Ministerio de Ciencia, Innovación y Universidades and FEDER, with the project PGC2018-095456-B-I00.

\section{Disclosure}

M. Sepulveda received speaking honoraria from Novartis and Roche and travel reimbursement from Biogen. S. Llufriu received speaking honoraria from Biogen Idec, Novartis, Teva, Genzyme, and Merck and receives research support from the Spanish Government (PI15/00587). E. Martínez-Hernández, M. Català, M. Artola, A. Hernando, and C. Montejo report no disclosures. I. Pulido-Valdeoliva received travel reimbursement from Roche, Novartis, and Genzyme, holds stock options in Aura Innovative Robotics, and is currently an employee at UCB Pharma. E. Martínez-Heras and M. Guasp report no disclosures. E. Solana received travel reimbursement from Teva and Sanofi. L. Llansó, D. Escudero, M. Aldea, and C. Prats report no disclosures. F. Graus receives royalties from Euroimmun for the use of IgLON5 and honoraria for serving as an assistant editor of MedLink Neurology. Y. Blanco received speaking honoraria from Biogen, Novartis, and Genzyme. A. Saiz reports compensation for consulting services and speaker honoraria from Merck Serono, Biogen Idec, Sanofi Aventis, Teva Pharmaceutical Industries Ltd., Novartis, Roche, and Alexion. Go to Neurology.org/NN for full disclosures.

\section{Publication History}

Received by Neurology: Neuroimmunology \& Neuroinflammation September 22, 2020. Accepted in final form November 20, 2020.

Appendix Authors

\begin{tabular}{lll}
\hline Name & Location & Contribution \\
\hline $\begin{array}{l}\text { Maria } \\
\text { Sepúlveda, MD }\end{array}$ & $\begin{array}{l}\text { Hospital Clinic, } \\
\text { Barcelona, Spain }\end{array}$ & $\begin{array}{l}\text { Drafted the first version of the } \\
\text { manuscript; analyzed the data; } \\
\text { acquisition of clinical data; and } \\
\text { revised the manuscript for } \\
\text { intellectual content }\end{array}$
\end{tabular}

\begin{tabular}{lll}
\hline $\begin{array}{l}\text { Sara Llufriu, } \\
\text { MD, PhD }\end{array}$ & $\begin{array}{l}\text { Hospital Clinic, } \\
\text { Barcelona, Spain }\end{array}$ & $\begin{array}{l}\text { Drafted the first version of the } \\
\text { manuscript; analyzed the data; } \\
\text { acquisition of clinical data; and } \\
\text { revised the manuscript for } \\
\text { intellectual content }\end{array}$ \\
$\begin{array}{l}\text { Eugenia } \\
\begin{array}{l}\text { Martínez- } \\
\text { Hernández, MD, } \\
\text { PhD }\end{array}\end{array}$ & $\begin{array}{l}\text { Hospital Clínic and } \\
\text { IDIBAPS, } \\
\text { Barcelona, Spain }\end{array}$ & $\begin{array}{l}\text { Acquisition of clinical data and } \\
\text { revised the manuscript for } \\
\text { intellectual content }\end{array}$ \\
\hline
\end{tabular}

Continued 


\begin{tabular}{|c|c|c|}
\hline $\begin{array}{l}\text { Martí Català, } \\
\text { MSc }\end{array}$ & $\begin{array}{l}\text { UPC, Barcelona, } \\
\text { Spain }\end{array}$ & $\begin{array}{l}\text { Analyzed the data and revised } \\
\text { the manuscript for intellectual } \\
\text { content }\end{array}$ \\
\hline $\begin{array}{l}\text { Montse Artola, } \\
\text { RN }\end{array}$ & $\begin{array}{l}\text { IDIBAPS, } \\
\text { Barcelona, Spain }\end{array}$ & $\begin{array}{l}\text { Acquisition of clinical data and } \\
\text { revised the manuscript for } \\
\text { intellectual content }\end{array}$ \\
\hline $\begin{array}{l}\text { Ana Hernando, } \\
\text { RN }\end{array}$ & $\begin{array}{l}\text { Hospital Clínic, } \\
\text { Barcelona, Spain }\end{array}$ & $\begin{array}{l}\text { Acquisition of clinical data and } \\
\text { revised the manuscript for } \\
\text { intellectual content }\end{array}$ \\
\hline $\begin{array}{l}\text { Carmen } \\
\text { Montejo, MD }\end{array}$ & $\begin{array}{l}\text { Hospital Clinic, } \\
\text { Barcelona, Spain }\end{array}$ & $\begin{array}{l}\text { Acquisition of clinical data and } \\
\text { revised the manuscript for } \\
\text { intellectual content }\end{array}$ \\
\hline $\begin{array}{l}\text { Irene Pulido- } \\
\text { Valdeolivas, } \\
\text { MD, PhD }\end{array}$ & $\begin{array}{l}\text { Hospital Clinic, } \\
\text { Barcelona, Spain }\end{array}$ & $\begin{array}{l}\text { Acquisition of clinical data and } \\
\text { revised the manuscript for } \\
\text { intellectual content }\end{array}$ \\
\hline $\begin{array}{l}\text { Eloy Martínez- } \\
\text { Heras, PhD }\end{array}$ & $\begin{array}{l}\text { IDIBAPS, } \\
\text { Barcelona, Spain }\end{array}$ & $\begin{array}{l}\text { Acquisition of clinical data and } \\
\text { revised the manuscript for } \\
\text { intellectual content }\end{array}$ \\
\hline Mar Guasp, MD & $\begin{array}{l}\text { Hospital Clinic, } \\
\text { Barcelona, Spain }\end{array}$ & $\begin{array}{l}\text { Acquisition of clinical data and } \\
\text { revised the manuscript for } \\
\text { intellectual content }\end{array}$ \\
\hline $\begin{array}{l}\text { Elisabeth } \\
\text { Solana, PhD }\end{array}$ & $\begin{array}{l}\text { IDIBAPS, } \\
\text { Barcelona, Spain }\end{array}$ & $\begin{array}{l}\text { Acquisition of clinical data and } \\
\text { revised the manuscript for } \\
\text { intellectual content }\end{array}$ \\
\hline $\begin{array}{l}\text { Laura Llansó, } \\
\text { MD }\end{array}$ & $\begin{array}{l}\text { Hospital Clinic, } \\
\text { Barcelona, Spain }\end{array}$ & $\begin{array}{l}\text { Acquisition of clinical data and } \\
\text { revised the manuscript for } \\
\text { intellectual content }\end{array}$ \\
\hline $\begin{array}{l}\text { Domingo } \\
\text { Escudero, MD, } \\
\text { PhD }\end{array}$ & $\begin{array}{l}\text { Hospital Clínic, } \\
\text { Barcelona, Spain }\end{array}$ & $\begin{array}{l}\text { Acquisition of clinical data and } \\
\text { revised the manuscript for } \\
\text { intellectual content }\end{array}$ \\
\hline $\begin{array}{l}\text { Marta Aldea, } \\
\text { MD, MPH }\end{array}$ & $\begin{array}{l}\text { Hospital Clínic, } \\
\text { Barcelona, Spain }\end{array}$ & $\begin{array}{l}\text { Acquisition of clinical data and } \\
\text { revised the manuscript for } \\
\text { intellectual content }\end{array}$ \\
\hline Clara Prats, PhD & $\begin{array}{l}\text { UPC, Barcelona, } \\
\text { Spain }\end{array}$ & $\begin{array}{l}\text { Analysis and interpretation of } \\
\text { the data and revised the } \\
\text { manuscript for intellectual } \\
\text { content }\end{array}$ \\
\hline $\begin{array}{l}\text { Francesc Graus, } \\
\text { MD, PhD }\end{array}$ & $\begin{array}{l}\text { IDIBAPS, } \\
\text { Barcelona, Spain }\end{array}$ & $\begin{array}{l}\text { Analysis and interpretation of } \\
\text { the data and revised the } \\
\text { manuscript for intellectual } \\
\text { content }\end{array}$ \\
\hline $\begin{array}{l}\text { Yolanda Blanco, } \\
\text { MD, PhD }\end{array}$ & $\begin{array}{l}\text { Hospital Clinic, } \\
\text { Barcelona, Spain }\end{array}$ & $\begin{array}{l}\text { Designed and conceptualized } \\
\text { the study; acquisition of clinical } \\
\text { data; analysis and } \\
\text { interpretation of the data; and } \\
\text { revised the manuscript for } \\
\text { intellectual content }\end{array}$ \\
\hline $\begin{array}{l}\text { Albert Saiz, MD, } \\
\text { PhD }\end{array}$ & $\begin{array}{l}\text { Hospital Clinic, } \\
\text { Barcelona, Spain }\end{array}$ & $\begin{array}{l}\text { Drafted the last version of the } \\
\text { manuscript; designed and } \\
\text { conceptualized the study; } \\
\text { acquisition of clinical data; } \\
\text { analysis and interpretation of } \\
\text { the data; and revised the } \\
\text { manuscript for intellectual } \\
\text { content }\end{array}$ \\
\hline
\end{tabular}

\section{References}

1. Zhou F, Yu R, Du R, et al. Clinical course and risk factors for mortality of adult inpatients with COVID-19 in Wuhan, China: a retrospective cohort study. Lancet 2020;395:1054-1062.

2. Richardson S, Hirsch JS, Narasimhan M, et al. Presenting characteristics, comorbidities, and outcomes among 5700 patients hospitalized with COVID-19 in the New York City area. JAMA 2020;323:2052-2059.

3. Louapre C, Collongues N, Stankoff B, et al. Clinical characteristics and outcomes in patients with coronavirus disease 2019 and multiple sclerosis. JAMA Neurol 2020;77: 1079-1088.

4. Berger J, Brandstadter R, Bar-Or A. COVID-19 and MS disease-modifying therapies. Neurol Neuroimmunol Neuroinflamm 2020;7:e761. doi: 10.1212/NXI.0000000000000761.

5. Brownlee W, Bourdette D, Broadley S, Killestein J, Ciccarelli O. Treating multiple sclerosis and neuromyelitis optica spectrum disorder during the COVID-19 pandemic. Neurology 2020;94:949-952.

6. Fan M, Qiu W, Bu B, et al. Risk of COVID-19 infection in MS and neuromyelitis optica spectrum disorders. Neurol Neuroimmunol Neuroinflamm 2020;7:e787. doi: 10.1212/NXI.0000000000000787.

7. World Health Organization. Global Surveillance for COVID-19 Caused by Human Infection with COVID-19 Virus: Interim Guidance, 20 March 2020. Geneva: World Health Organization. Available at: apps.who.int/iris/handle/10665/331506. License: CC BY-NC-SA 3.0 IGO. Accessed August 26, 2020.

8. Kurtzke JF. Rating neurologic impairment in multiple sclerosis: an expanded disability status scale (EDSS). Neurology 1983;33:1444-1452.

9. Departament de Salut. COVID data. Register of COVID-19 cases carried out in Catalonia. Segregation by gender and age. Available at: dadescovid.cat/descarregues? lang=eng. Accessed September 17, 2020.

10. Parrotta E, Kister I, Charvet L, et al. COVID-19 outcomes in MS. Observational study of early experience from NYU multiple sclerosis comprehensive care center. Neurol Neuroimmunol Neuroinflamm 2020;7:e835. doi: 10.1212/NXI.0000000000000835.

11. Evangelou N, Garjani A, dasNair R, et al. Self-diagnosed COVID-19 in people with multiple sclerosis: a community-based cohort of the UK MS Register. J Neurol Neurosurg Psychiatry Epub 2020 August 27.

12. Moss BP, Mahajan KR, Bermel RA, et al. Multiple sclerosis management during the COVID-19 pandemic. Mult Scler 2020;26:1163-1171.

13. Michelena X, Borrell H, López-Corbeto M, et al. Incidence of COVID-19 in a cohort of adult and paediatric patients with rheumatic diseases treated with targeted biologic and synthetic disease-modifying anti-rheumatic drugs. Semin Arthritis Rheum 2020;50:564-570.

14. Crescenzo F, Marastoni D, Bovo C, Calabrese M. Frequency and severity of COVID19 in multiple sclerosis: a short single-site report from northern Italy. Mult Scler Relat Disord 2020;44:102372.

15. Sormani P, De Rossi N, Schiavetti I, et al. Disease modifying therapies and COVID-19 severity in multiple sclerosis. Lancet. Available at SRN: ssrn.com/abstract=3631244 or dx.doi.org/10.2139/ssrn.3631244. Accessed September 16, 2020.

16. Sahraian MA, Azimi A, Navardi S, Ala S, Moghadasi AN. Evaluation of the rate of COVID-19 infection, hospitalization and death among Iranian patients with multiple sclerosis. Mult Scler Relat Disord 2020;46:102472.

17. Sormani MP and the Italian Study Group on COVID-19 infection in multiple sclerosis. An Italian programme for COVID-19 infection in multiple sclerosis. Lancet Neurol 2020;19:481-482.

18. Loonstra FC, Hoitsma E, van Kempen Z, et al. COVID-19 in multiple sclerosis: the Dutch experience. Mult Scler 2020;26:1256-1260. 


\title{
Neurology \\ Neuroimmunology \& Neuroinflammation
}

\author{
Incidence and Impact of COVID-19 in MS: A Survey From a Barcelona MS Unit \\ Maria Sepúlveda, Sara Llufriu, Eugenia Martínez-Hernández, et al. \\ Neurol Neuroimmunol Neuroinflamm 2021;8; \\ DOI 10.1212/NXI.0000000000000954
}

This information is current as of January 27, 2021

\section{Updated Information \& Services}

References

Citations

Subspecialty Collections

Permissions \& Licensing

Reprints including high resolution figures, can be found at: http://nn.neurology.org/content/8/2/e954.full.html

This article cites 14 articles, 3 of which you can access for free at: http://nn.neurology.org/content/8/2/e954.full.html\#\#ref-list-1

This article has been cited by 1 HighWire-hosted articles: http://nn.neurology.org/content/8/2/e954.full.html\#\#otherarticles

This article, along with others on similar topics, appears in the following collection(s):

COVID-19

http://nn.neurology.org//cgi/collection/covid_19

Incidence studies

http://nn.neurology.org//cgi/collection/incidence_studies

Multiple sclerosis

http://nn.neurology.org//cgi/collection/multiple_sclerosis

Information about reproducing this article in parts (figures,tables) or in its entirety can be found online at:

http://nn.neurology.org/misc/about.xhtml\#permissions

Information about ordering reprints can be found online: http://nn.neurology.org/misc/addir.xhtml\#reprintsus

Neurol Neuroimmunol Neuroinflamm is an official journal of the American Academy of Neurology.

Published since April 2014, it is an open-access, online-only, continuous publication journal. Copyright

Copyright $\left({ }^{\circ} 2021\right.$ The Author(s). Published by Wolters Kluwer Health, Inc. on behalf of the American

Academy of Neurology.. All rights reserved. Online ISSN: 2332-7812.

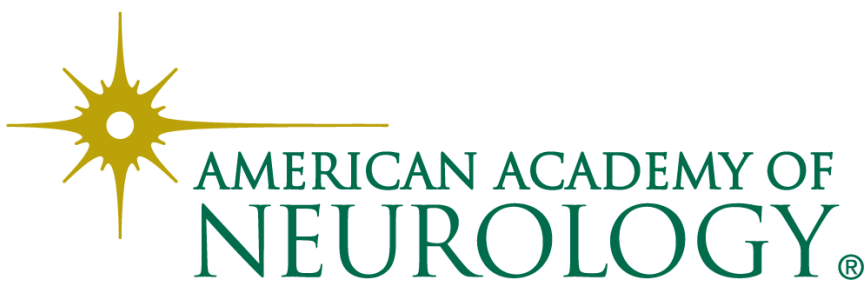

